\title{
Life-threatening right ventricular thrombosis in association with phospholipid antibodies
}

\author{
Stephen O’Hickey, Craig Skinner, James Beattie
}

\begin{abstract}
An 18 year old man presented with cough and dyspnoea caused by pulmonary infarction. A large friable mass of organising thrombus in an anatomically normal right ventricle was identified as an embolic source. The acute illness was associated with raised titres of anticardiolipin antibodies, one of the antiphospholipid group. This thrombus recurred after surgical removal but subsequently was dissipated after treatment with oral corticosteroids and long-term oral anticoagulation.
\end{abstract}

(Br Heart F 1993;70:279-281)

Antibodies to phospholipids including anticardiolipin antibodies and the lupus anticoagulant have been widely described in relation both to connective tissue disorders and as a primary phenomenon. ${ }^{1-3}$ Their presence has been associated with venous and arterial thrombotic events although the precise nature of the underlying coagulopathy is unknown. Several cardiac disorders have been linked to these substrates including vein graft attrition and prosthetic valve dysfunction, ${ }^{4-6}$ but intracardiac thrombosis seems to be relatively rare. ${ }^{78}$ We describe the clinical sequelae of phospholipid antibody induced thrombosis occurring in a morphologically normal right ventricle.

\section{Case report}

An 18 year old man was admitted with a three month history of malaise, anorexia, dry cough, and pleuritic chest pain. These symptoms had persisted despite several courses of oral antibiotics. His medical history did not clarify the situation and he denied intravenous drug abuse. His mother was of mixed Italian and southern Asian descent, his father was white, and there was no known family history of thrombotic disease.

Examination showed an intermittent fever. There was no oral ulceration, ocular abnormality, or rash, nor any evidence of arthritis or deep venous thrombosis. He had a large superficial sore on the left of his scrotum without associated lymphadenopathy. This healed initially, to recur in a milder form later in the illness. Clinical examination of the cardiovascular system was normal as was an electrocardiogram. A small right pleural effusion was evident both clinically and radiologically and the chest $\mathbf{x}$ ray film also showed a well defined rounded mass in the right lower lobe.

He continued to show a swinging pyrexia with associated polymorphonuclear leucocytosis (maximally $28.2 \times 10^{9} / 1$ ) although multiple blood cultures were negative. This fever persisted despite intravenous broad spectrum antibiotics and further cultures for common and atypical bacteria, viral, and fungal pathogens were persistently negative. He exhibited a mild normochromic normocytic anaemia (haemoglobin $11.2 \mathrm{~g} / \mathrm{dl}$ ). A clotting screen was abnormal with a prolonged prothrombin ratio of 1.5 (normal range 1.0-1.2) and raised fibrin degradation products of $>10000 \mu \mathrm{g} / 1$ (normal range $<10 \mu \mathrm{g} / 1$ ) with platelets of $252 \times 10^{9} / 1$.

An exploratory right thoracotomy was performed. A large spongy mass was excised from the right lower lobe. Histologically this was a necrotic pulmonary infarct with associated intrapulmonary haemorrhage and with evidence of recanalised thrombotic lesions in the pulmonary circulation. There was no evidence of vasculitis or malignancy. A subsequent ventilation and perfusion lung scan showed several mismatched defects bilaterally. He was prescribed intravenous heparin.

Ultrasound examinations of the abdomen, pelvis, and scrotum were normal as were Doppler studies of the inferior vena cava, the common femoral, superficial femoral, and popliteal veins.

Echocardiography showed a large mobile mass in the right ventricle, which looked like an intracardiac thrombus. This was attached at the right ventricular apex and at the interventricular septum close to the septal tricuspid leaflet, but Doppler studies did not suggest any obstruction to right ventricular flow.

He was referred for cardiac surgery and an irregular necrotic mass the size of a golf ball was excised from the right ventricle. This proved difficult to interpret histologically and sections were reviewed by the ICRF/RCS (Eng) Histopathology Unit Panel. The consensus was that this mass consisted of partially autolysed thrombus containing a few inflammatory cells. The areas of attachment on the ventricular wall showed the myocardium to be partly replaced by inflamed granulation tissue and fibrosis.
Correspondence to: Dr J M Beattie, Department of Cardiology, East Birmingham Hospital, Birmingham B9 5ST.

Department of
Cardiology
S P O'Hickey
J M Beattie
Department of
Respiratory Medicine,
East Birmingham
Hospital, Birmingham
C S Skinner
Correspondence to:
Dr J M Beattie, Department
of Cardiology, East
Birmingham Hospital,
Bordesley Green East,
Birmingham B9 5ST.


He improved symptomatically after operation and was discharged having been prescribed warfarin to achieve an international normalised ratio (INR) of $2 \cdot 4$.

He presented with further minor intermittent haemoptysis one month after thrombectomy and repeat echocardiography showed recurrence of intracardiac thrombus seen as multiple elongated columns within the right ventricle. This thrombus seemed to progress despite 72 hours of adequate intravenous anticoagulation with heparin, and as antiphospholipid antibodies were found to be raised immunosuppression with oral prednisolone $(0.5 \mathrm{mg} / \mathrm{kg}$ daily) was started.

The next day he had a massive haemoptysis (estimated blood loss 2 l) and required emergency right lower lobectomy. As previously, histology showed only haemorrhagic pulmonary infarction. Steroid treatment was continued perioperatively and anticoagulation with warfarin was cautiously reintroduced after the operation and continued long-term.

Over a follow up period of two years he remains stable with mild effort dyspnoea (New York Heart Association grade II). Despite maintenance steroid treatment of 5 mg prednisolone daily and anticoagulation to achieve an INR within the therapeutic range $(2 \cdot 0-2 \cdot 5)$, he has continued to have mild attacks of haemoptysis.

Sequential echocardiography shows no further recurrence of right ventricular thrombosis.

\section{SEROLOGY}

Serological studies in this patient showed negative results for antinuclear antibody, extractable nuclear antigens, and both single stranded and double stranded DNA. Pathergy tests for Behçet's disease were consistently negative as were the VDRL tests. There was a polyclonal increase in immunoglobulins with C-reactive protein maximally estimated at $220 \mathrm{mg} / \mathrm{l}$. Lupus anticoagulant was not detected. Anticardiolipin antibody concentrations were estimated by a previously described enzyme-linked immunosorbent assay (ELISA) ${ }^{9}$ and calibrated against international standard serum samples. This assay showed an initial moderate increase in the IgG isotype at $26.0 \mathrm{GPLU} / \mathrm{ml}$, (normal $<5$ GPLU $/ \mathrm{ml}$ ) that was stable over the period of cardiac surgery and was normal two weeks after starting steroid treatment. The IgM anticardiolipin isotype was consistently normal at $<1 \mathrm{MPLU} / \mathrm{ml}$. The table shows detailed response of these anticardiolipin antibodies over the early course of the illness.

Changes in anticardiolipin antibody titre (PLU/ml)

\begin{tabular}{lrll}
\hline & & \multicolumn{2}{l}{$\begin{array}{l}\text { Anticardiolipin antibody } \\
\text { isotypes }\end{array}$} \\
\cline { 5 - 5 } \cline { 4 - 4 } Event & Day & $\operatorname{Ig} G(<8 \cdot 0)^{\star}$ & $\operatorname{IgM}(<5 \cdot 4)^{\star}$ \\
\hline At presentation & 01 & $26 \cdot 0$ & $<1$ \\
After thrombectomy & 33 & $29 \cdot 0$ & $<1$ \\
After two-weeks of steroid treatment & 60 & $5 \cdot 3$ & $<1$ \\
At later outpatient reviews & 126 & $4 \cdot 4$ & $<1$ \\
& 154 & $3 \cdot 5$ & $<1$ \\
\hline
\end{tabular}

^Normal ranges are shown.

\section{Discussion}

Phospholipid antibodies including anticardiolipin antibodies and the lupus anticoagulant may occur in various connective tissue disorders but notably in systemic lupus erythematosus or lupus-like disease. Such antibodies have also been reported in Behçet's disease, with some acute infections, and have been implicated as a cause of thrombocytopenia and recurrent miscarriage. ${ }^{1011}$

The precise aetiology of the cardiac thrombosis in this patient is difficult to ascertain, but in the absence of clinical or serological evidence of systemic lupus erythomatosus, the diagnosis of a primary antiphospholipid syndrome may be applied. ${ }^{12}$ Behçet's disease was also considered given the patients racial background and history of genital ulceration, but based on accepted diagnostic criteria, this would have been a forme fruste of Behçet's at best. ${ }^{1314}$ There have been several reports of intracardiac thrombosis in Behçet's disease, ${ }^{15-17}$ but in none of these cases were anticardiolipin antibody titres measured, and when this antibody activity has been estimated in Behçet's disease associated with thrombotic events remote from the heart, there seems to be a less consistent rise of IgG anticardiolipin and $\operatorname{IgM}$ activity may dominate. ${ }^{1018}$

Intracardiac thrombosis in association with raised anticardiolipin antibodies has only previously been reported in two female patients who exhibited lupus seropositivity. Leventhal et al described a patient with systemic lupus erythematosus presenting with right atrial thrombosis mimicking right atrial myxoma, ${ }^{7}$ and Coppock et al described a patient with a lupus like syndrome who presented with right ventricular thrombosis occurring in a two chambered right ventricle. ${ }^{8}$ Histology in these patients was similar to our own findings and both showed a moderate rise in the IgG cardiolipin antibody isotype titre and a normal IgM isotype concentration. It has been suggested that the IgG anticardiolipin antibody isotype may be the predominant thrombogenic agent and that IgM activity may be less important. ${ }^{11}$

The mechanism of the thrombogenicity of anticardiolipin antibodies activity remains ill defined. It is possible that these substrates directly injure the endothelium with resultant thrombosis. ${ }^{11}$ This mechanism is unlikely, however, and it is more probable that when damage is initiated by an underlying autoimmune process the presence of these antibodies mediates the secondary deposition of thrombus. ${ }^{19}$ Interestingly, increased phospholipid antibody in AIDS associated diseases seems to be less thrombogenic. ${ }^{20}$

The mechanism of thrombosis in the absence of a discernible connective tissue disorder as a primary phospholipid antibody syndrome is even more speculative. Several hypotheses have emerged. These antibodies seem to bind preferentially with the phosphodiester group of negatively charged phospholipids, an effect that may interact with the coagulation cascade at the stage of conversion 
of prothrombin to thrombin. ${ }^{12} \mathrm{~A}$ similar interaction may adversely affect platelet membrane function promoting aggregation. ${ }^{1}$ Carreras et al have also proposed a potential effect on endothelial cell function leading to a decrease in prostacyclin release, ${ }^{21}$ and more recently, interference with the endogenous anticoagulant functions of protein $\mathrm{C}$ and protein $\mathrm{S}$ has been shown. ${ }^{9}$

The current lack of definition of the pathogenetic mechanisms of phospholipid antibody syndromes precludes specific therapeutic measures at present, and the isolated finding of a raised antibody concentration is not in itself an indication for treatment. For thrombotic disease associated with phospholipid antibody, conventional treatment is based on immunosuppression, anticoagulation, or antiplatelet treatment, used either singly or in combination. When there is an underlying associated connective tissue disease, immunosuppression seems to be logical, and may also be justified if there is a poor response to anticoagulation as in the case described. Various methods have been used including corticosteroids, cytotoxic drugs, high dose immunoglobulins, and plasma exchange but no consensus for the use of such treatment exists. ${ }^{22}$ Isolated antiplatelet treatment or intermittent subcutaneous low molecular weight heparin may not provide adequate protection in most patients, although in pregnancy this may be particularly useful in preventing recurrent miscarriage or retardation of fetal growth due to placental thrombosis.

The cornerstone of treatment in most cases is anticoagulation with warfarin. This treatment should continue indefinitely as there is a high rate or recurrence of thrombosis, reported at $53 \%$ in a recent series for a variety of treatment regimens. ${ }^{23}$ Recurrent thrombosis seems particularly common shortly after withdrawal of warfarin treatment, and the degree of continuing antiphospholipid reaction may not be a marker for such events. ${ }^{24}$ Intermediate intensity (INR 2.0 to $2 \cdot 9$ ) or high intensity (INR >3.0) anticoagulation seems to provide more protection than low intensity treatment (INR <1.9), ${ }^{23}$ and Asherson and Cervera have recently suggested a target INR between 3.0 and $3 \cdot 5 .^{4}$ In some patients who are affected by particularly active hypercoagulation, high doses of warfarin may be required to achieve such therapeutic ratios.

This case further confirms the heterogeneous nature of thrombosis associated with antiphospholipid syndromes and shows the necessity for a systematic approach to the investigation of these patients who may require immunosuppression and aggressive anticoagulation.
We gratefully acknowledge the contributions of Mr F Collins, Mr J Parmar, and Dr M Greaves. We are particularly indebted to $\mathrm{Dr} \mathrm{D}$ Creagh of the Royal Hallamshire Hospital, Deful discussion and for estimation of anticardiolipin antibody concentrations.

1 Bowie EJ, Thomson JH, Pascuzzi CA, Owen CA. Thrombosis in systemic lupus erythematosus. $f \mathrm{Lab}$ Clin Med 1963;62:416-30.

2 Hughes GR, Harris EN, Gharavi AE. The anticardiolipin syndrome. F Rheumatol 1986;13:486-9.

3 Mackworth-Young CG, Loizou S, Walport MJ. Primary antiphospholipid syndrome: features of patients with raised anticardiolipin antibodies and no other disorder. Ann Rheum Dis 1989;48:362-7.

4 Asherson RA, Cervera R. Antiphospholipid antibodies and the heart. Lessons and pitfalls for the cardiologist. Circulation 1991;84:920-3.

5 Morton KE, Gavaghan TP, Krilis SA, Daggard GE, Baron DW, Hickie JB, et al. Coronary artery bypass graft failure: an autoimmune phenomenon? Lancet 1986;ii:1353-6.

6 Lubbe WF, Asherson RA. Intracardiac thrombus in systemic lupus erythematosus associated with lupus anticoagulant. Arthritis Rheum (letter) 1988;31:1453-4.

7 Leventhal LJ, Borofsky MA, Bergey PD, Schumacher HR Antiphospholipid antibody syndrome with right atrial thrombosis mimicking an atrial myxoma. Am $\mathcal{f}$ Med 1989;87:111-3.

8 Coppock MA, Safford RE, Danielson GK. Intracardiac thrombosis, phospholipid antibodies and two-chamthrombosis, phospholipid antibodies and two-c

9 Malia RG, Kitchen S, Greaves M, Preston FE. Inhibition of activated protein $C$ and its cofactor protein $S$ by of activated protein $C$ and its cofactor protein $S$ by
antiphospholipid antibodies. $B r f$ Haematol 1990; antiphosp

10 Hull RG, Harris EN, Gharavi AE, Tincani A, Asherson RA, Valesini G, et al. Anticardiolipin antibodies: occurrence in Behçet's syndrome. Ann Rheum Dis 1984; 43:747-8.

11 Hughes GRV, Asherson RA, Khamashta MA. Antiphospholipid syndrome: linking many specialities. Ann Rheum Dis 1989;48:355-6.

12 Asherson RA, Khamashta MA, Ordi-Ros J, Derksen RHWM, Machin SJ, Barquinero J, et al. The "primary" antiphospholipid syndrome: major clinical and serological features. Medicine (Baltimore) 1989;68:366-74.

13 International Study Group for Behçet's Disease. Criteria for diagnosis of Behçet's disease. Lancet 1990;335: for diagn

14 Raz I, Okon E, Chajek-Shaul T. Pulmonary manifestations of Behçet's disease. Chest 1989;95:585-9.

15 Candan I, Erol C, Sonel A, Akalin H. Behçet's disease: cardiac and pulmonary involvement. Eur Heart f 1986; 7:999-1002

16 Vanhaleweyk G, El-Ramahi KM, Hazmi M, Sieck JO, Zaman L, Fawzy M. Right atrial, right ventricular and left ventricular thrombi in (incomplete) Behçet's disease. Eur Heart f 1990;11:957-9.

17 Imai H, Sakakibara M, Yoshida K, Watanabe S, Masuda $\mathrm{Y}$, Inagaki $\mathrm{Y}$, et al. Magnetic resonance imaging of cardiovascular thrombi. $f$ Cardiography 1985;15: 681-94.

18 Bergman $R$, Lorber $M$, Lerner $M$, Brik R, FriedmanBirnbaum R. Anticardiolipin antibodies in Behçet's disease. F Dermatol 1990;17:164-7.

19 Leung W-H, Wong K-L, Lau C-P, Wong C-K, Liu H-W Association between antiphospholipid antibodies and cardiac abnormalities in patients with systemic lupus cardiac abnormalites in patients with

20 Stimmler MM, Quismorio FP, McGhee WG, Boylen T, Sharma OP. Anticardiolipin antibodies in acquired Sharma OP. Anticardiolipin antibodies in acquired
immune deficiency syndrome. Arch Intern Med 1989; immune defici

21 Carreras LO, Defreyn G, Machin SJ. Arterial thrombosis, intrauterine death and lupus anticoagulant: detection of immunoglobulin interfering with prostacyclin formation. Lancet $1981 ; \mathbf{i}: 244-6$.

22 Khamashta MA, Wallington T. Management of the antiphospholipid syndrome. Ann Rheum Dis 1991;50: 959-62.

23 Rosove MH, Brewer PMC. Antiphospholipid thrombosis: clinical course after the first thrombotic event in 70 patients. Ann Intern Med 1992;117:303-8.

24 Asherson RA, Harris EN, Gharavi AE, Hughes GRV. Anticardiolipin antibody, recurrent thrombosis and warfarin withdrawal. Ann Rheum Dis 1985;44:823-5. 